\title{
GEORADAR INVESTIGATION AT THE KEDULAN TEMPLE EXCAVATION SITE, KALASAN, YOGYAKARTA
}

\author{
Salahuddin Husein*1, Saptono Budi Samodra ${ }^{1}$, Subagyo Pramumijoyo ${ }^{1}$, and Wahyu \\ Astuti $^{2}$ \\ ${ }^{1}$ Department of Geological Engineering, Faculty of Engineering, Gadjah Mada University, Jl. Grafika 02, Yogyakarta \\ 55281, Indonesia \\ ${ }^{2}$ Archaelogical Office of Yogyakarta, Bogem, Kalasan, Sleman, Yogyakarta
}

\begin{abstract}
Kedulan Site is the buried and ruined $9^{\text {th }}$ century Mataram Hindu Kingdom temple, located in Tirtomartani Village, Kalasan District, Sleman Regency, Yogyakarta Special Province. This temple was incidentally discovered by sand diggers on 24 November 1993 under several meter thick of fluviovolcanic deposit of the modern Merapi. Several technical studies were needed to carefully excavate the temple, including geology and geophysical approaches. One of the geophysical method have been applied was ground penetration radar (georadar). This method uses radar technology to obtain a continuous profile of the shallow sub-surface and thus allows scientists to image soil substratums based on differing dielectric constants. Georadar investigation by Department of Geological Engineering, Faculty of Engineering, Universitas Gadjah Mada, was conducted on 4 December 2007. The main purpose was to identify the location of the outer stone fence as an estimation to define the temple site area to be excavated. About one line was chosen to cross the site in north-south direction in a distance of $328 \mathrm{~m}$. Two runs were completed on the same line but different courses, i.e. forward and backward, where one was checked with another. The result indicates the presence of the outer stone fence was possibly buried in a depth of $7 \mathrm{~m}$. It was located about $40 \mathrm{~m}$ distance

\footnotetext{
${ }^{*}$ Corresponding author: SALAHUDDIN HUSEIN, Department of Geological Engineering, Faculty of Engineer55281, Indonesia. E-mail: shusein@ugm.ac.id
} ing, Gadjah Mada University, Jl. Grafika 02, Yogyakarta
\end{abstract}

outside the inner stone fence. Assuming the fences were quadrangle relative to the main temple, hence it is estimated that the site area to be excavated is about $13.830 \mathrm{~m}^{2}$ and total $96.808 \mathrm{~m}^{3}$ gravels and sands to be removed.

Keywords: With italic font shape

\section{Introduction}

Kedulan Site is a recently found temple which is located in Kedulan, Tirtomartani Village, Kalasan District, Sleman Regency, Yogyakarta Special Province. It was incidentally discovered by sand diggers on 24 November 1993 under few meters thick of fluvio-volcanic deposit of the modern Merapi. Since then, a series of rescue excavation has been conducting by the authority, i.e., Balai Pelestarian Peninggalan Purbakala Yogyakarta (Archaelogical Office of Yogyakarta). As part of the excavation programme, the Archaelogical Office in cooperation with Dinas Kebudayaan dan Pariwisata Kabupaten Sleman (Division of Culture and Tourism of Sleman Regency) since 2002 has been conducting a feasibility study to improve the excavation plan with several technical approaches. Geological and geophysical studies were applied to locate the buried temple materials and to understand about geo-chronological events those destroyed and buried the temple.

One of the geophysical approaches applied 
was ground penetration radar (georadar). It basically uses radar pulses to image the subsurface and is able to detect objects, changes in material, and voids and cracks. The main objective in applying georadar was to detect and locate the presence of the outer stone fence of the temple site. The result will be used further to expand the excavation plan.

\section{The Kedulan Temple Site}

The Kedulan Temple Site is located at 07.44.33,7 $\mathrm{S}$ and 110.28.11,1 $\mathrm{E}$ with average elevation about $168 \mathrm{~m}$ above sea level. It lies on a volcano lower slope with a gradient less than $8 \%$ and a horizontal distance to the Mount Merapi summit of $22 \mathrm{~km}$ (Figure 1). It is located between two main rivers, Gendol and Kuning, both are tributaries to Opak River downstream. Western part of the site was occupied by Gawe River, a tributary of the Kuning River.

The temple was built on the 9th century, which is based on historical evidences found in the Kedulan Site. Two inscriptions of Pananggaran and Sumundul, both were written in ancient Javanese language, indicate a year of 869 AD (Dinas Kebudayaan dan Pariwisata Kabupaten Sleman, 2004).

The Kedulan Site is composed of a main temple facing to the east with a dimension of 13.7 $\times 13.6$ meters (Figure 2). In a distance of $8.5 \mathrm{~m}$ to the east from the main temple, three small Perwara temples were found and aligned in north-south direction (Figure 3); the northern and southern ones have a length of $4.6 \mathrm{~m}$ whilst the middle one has a length of $5.4 \mathrm{~m}$. All those temples were build by andesitic blocks. Those four temples were located in a sacred yard enclosed by an inner fence in a dimension of 39.7 $\times 39.6 \mathrm{~m}$, which was build by tufaceous sandstone blocks. Based on comparison to other temples design of the same type and century (i.e., the Sambisari Temple, located about $4 \mathrm{~km}$ southwest of the Kedulan Site), it is hypothesized that there supposed to be an outer fence to enclose a profane yard (Dinas Kebudayaan dan Pariwisata Kabupaten Sleman, 2004). Previous geophysical investigation using VLF method suggests the presence of the outer fence in a dis- tance of $40 \mathrm{~m}$ from the inner fence (Dinas Kebudayaan dan Pariwisata Kabupaten Sleman, 2004; Sismanto and Hartantyo, 2006; Widiyanto and Sismanto, 2006).

The Kedulan Site was covered by lahar, pyroclastic and fluvial, altogether commonly named as fluvio-volcanic, deposits. Geological investigation on the excavation pits done by Department of Geological Engineering UGM indicates 14 layers of fluvio-volcanic deposits had covered the site with an average thickness of 7 m (Pramumijoyo et al., 2005) (Figure 4). This fact indicates that natural disaster such as volcanic eruptions was the one who ruined and destroyed the temple compound (Dinas Kebudayaan dan Pariwisata Kabupaten Sleman, 2004; Pramumijoyo et al., 2005; Mulyaningsih, 1999; 2006). The first volcanic eruption material deposited on $1285 \mathrm{AD}$ as given by a charcoal found in a volcanic ash layer above the temple floor (Newhall et al., 2000) (layer unit 2 in Figure 4). However, it is speculated that the site was firstly destroyed by an earthquake then later by the volcanic eruptions (Mulyaningsih et al., 2006). After several periods of fluvial deposition, lahar deposits again inundated the site on 1587 AD (Newhall et al., 2000; Mulyaningsih, 1999; 2006) (layer unit 7 (?) in Figure 4). Interrupted by a fluvial sedimentation, yet lahar again covered the site on 18th century (Mulyaningsih, 1999; 2006) (layer unit 9-11 (?) in Figure 4).

\section{Georadar}

Georadar uses radar technology to obtain a continuous profile of the surface. The basic principle is to send a directional magnetic pulse of 100 $\mathrm{MHz}$ to subsurface. This pulse, lasting only a few nanoseconds, will travel in the substratum materials until it encounters a boundary of differing dielectric constants. A portion of the signal is transmitted in the underneath layer and a portion is reflected to the surface to a receiving antenna. The strength, or amplitude, of the reflection is determined by the contrast in the dielectric constants of the two materials. Point reflectors will, due to spherical dispersion, be 


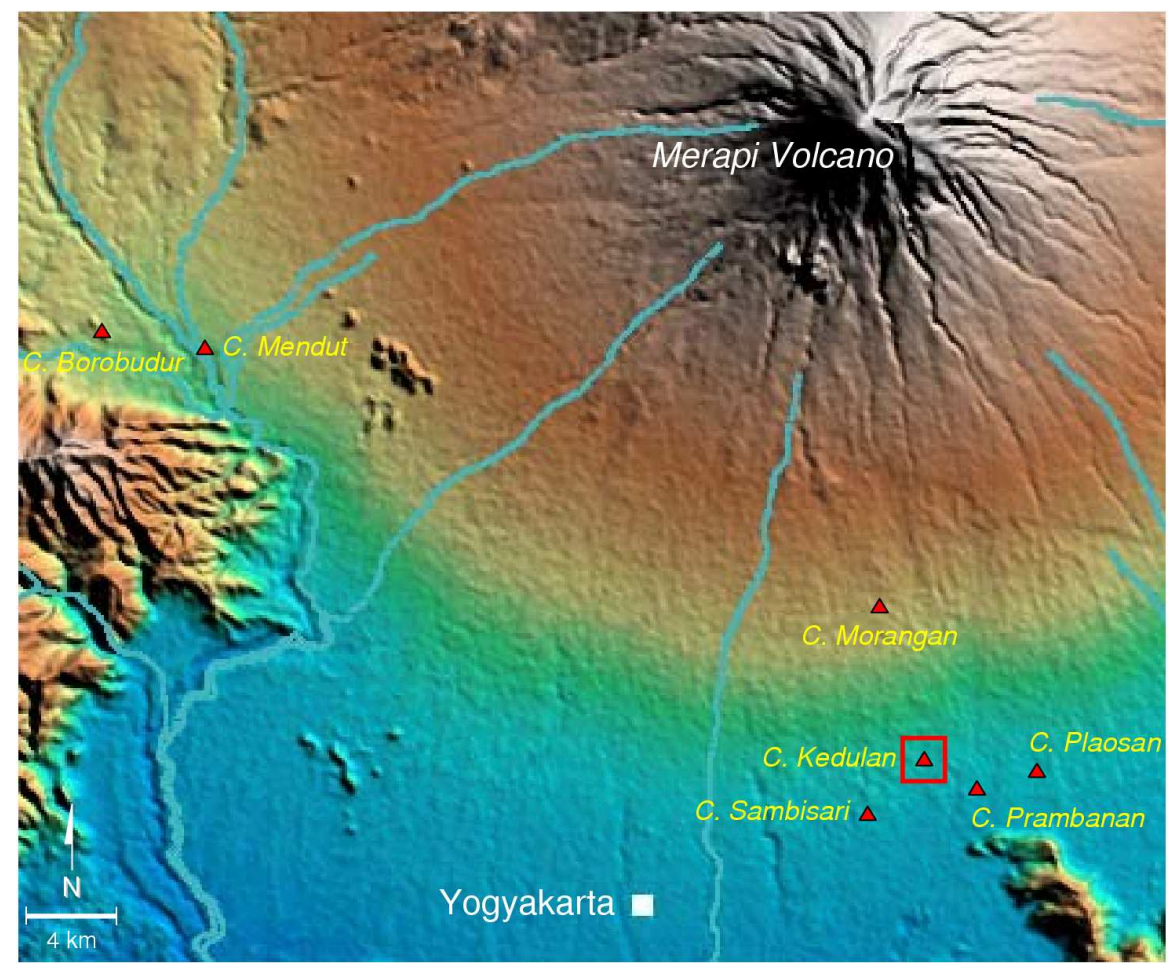

Figure 1: Location of the Kedulan Temple Site (red square line), relative to Yogyakarta City and Merapi Volcano, as well as to other temples around the Mt. Merapi. Background image is radar of SRTM NASA.

registered as hyperbolas, whilst plane reflectors will maintain their natural form (Figure 5).

This investigation used profiling method or line-scanned that measuring the reflection form objects located just below the antennas continuously. This method gives information about the horizontal location of the objects and rough estimate of its depth. In order to determine the depth of the object, Normal Move Out (NMO) correction was applied by fixing the position of the Common Midpoint (CMP) at one location. The reflected wave, which was located below the CMP, formed a hyperbolic curve, and the depth of the object and the velocity could be estimated simultaneously. The velocity used in this investigation is $145 \mathrm{~m} / \mu \mathrm{s}$, which is closed to the average velocity in the clayey sand (55 $150 \mathrm{~m} / \mu \mathrm{s})$ (Mala, 2005).

\section{Investigation Result}

Georadar investigation by Department of Geological Engineering UGM was conducted on 4 December 2007. One line was chosen to cross
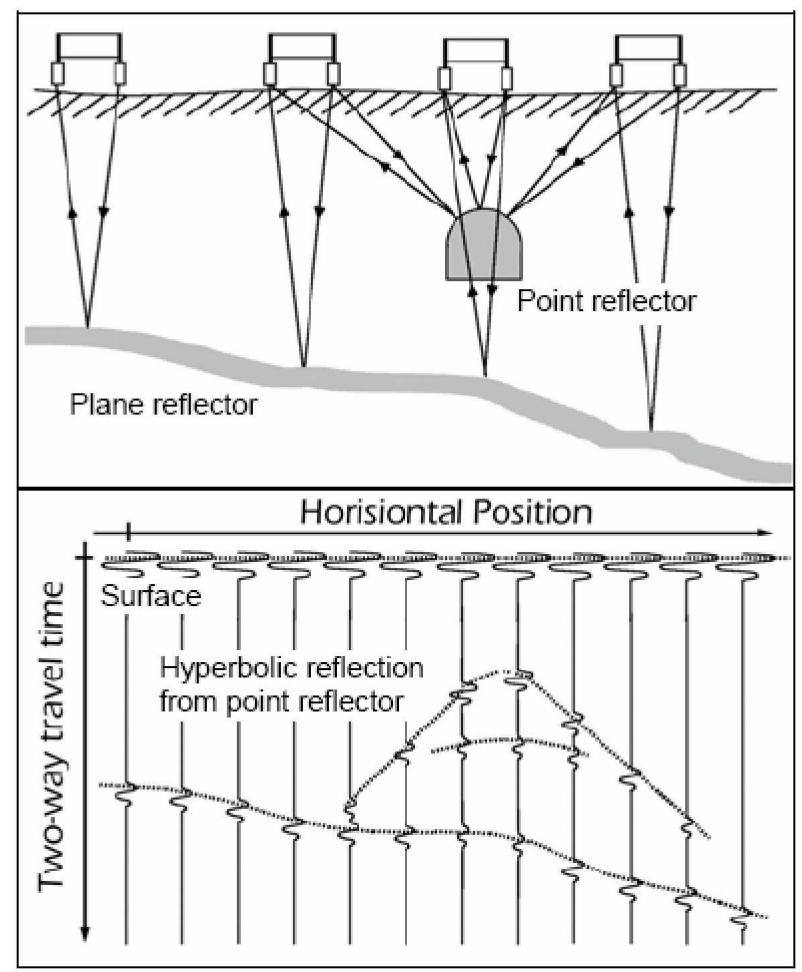

Figure 5: Reflection patterns of georadar in continuous profiling (Mala, 2005). 


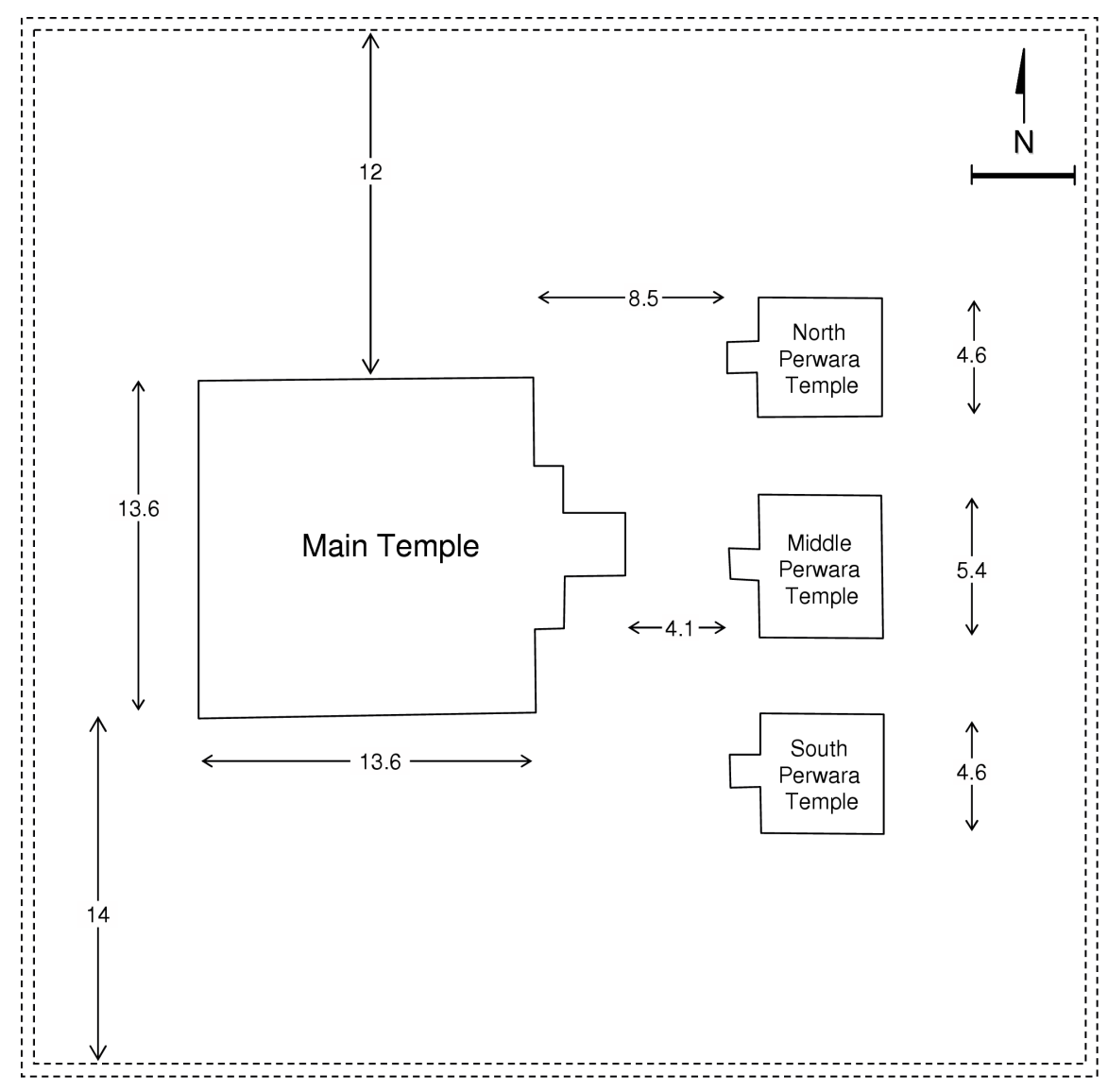

Figure 2: Schematic plan of the Kedulan Site (Dinas Kebudayaan dan Pariwisata Kabupaten Sleman, 2004). Distance unit is in meter.

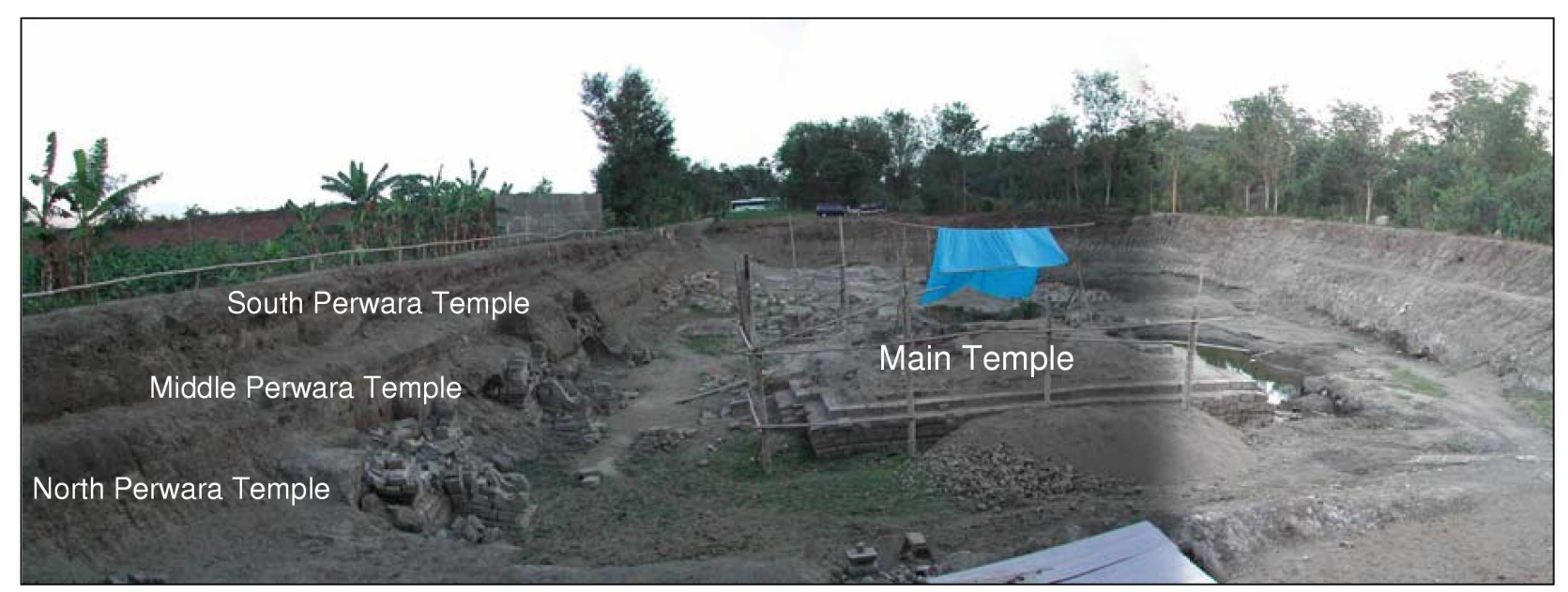

Figure 3: Excavation progress of the Kedulan Site by August 2006. Camera facing southward 


\begin{tabular}{|c|c|c|c|}
\hline Lithology & $\begin{array}{l}\text { Thickness } \\
(\mathrm{cm})\end{array}$ & Layer unit & Description \\
\hline \multirow{4}{*}{ 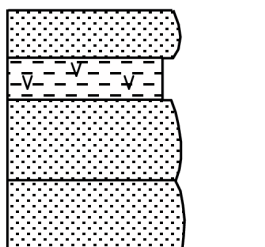 } & $<20$ & 15 & \multirow{4}{*}{ Intercalations of fluvial sand and pyroclastic tuf } \\
\hline & $<20$ & 14 & \\
\hline & $<40$ & 13 & \\
\hline & $<40$ & 12 & \\
\hline 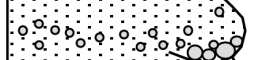 & \multirow{3}{*}{250} & 11 & \multirow{3}{*}{$\begin{array}{l}2-3 \text { sequences of lahar deposits, composed of normal } \\
\text { grading of boulder to sand. Floating fragments are } \\
\text { common near the bottom. }\end{array}$} \\
\hline $0: 0$ & & 10 & \\
\hline \multirow{3}{*}{ 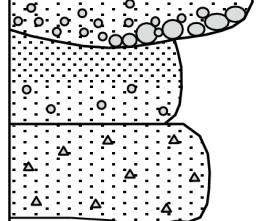 } & & 9 & \\
\hline & 150 & 8 & $\begin{array}{l}\text { Normal grading of coarse to medium sand. Lamination and } \\
\text { planar cross beds are common at the top. }\end{array}$ \\
\hline & $<80$ & 7 & $\begin{array}{l}\text { Gravelly sand, mainly composed of floating angular } \\
\text { scorian andesite fragments. }\end{array}$ \\
\hline \multirow{3}{*}{$-1=-1$} & $<6$ & 6 & Black clay with some small tree trunks. \\
\hline & $>30$ & 5 & Reddish brown sandy clay with paleosoil $<10 \mathrm{~cm}$. \\
\hline & $80-200$ & 4 & $\begin{array}{l}\text { Graded bedding gravelly sand. Lamination and planar } \\
\text { cross beds are common at the top. }\end{array}$ \\
\hline 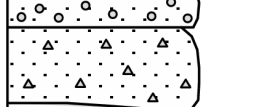 & $80-160$ & 3 & Massive gravelly sand with angular andesite fragments. \\
\hline \multirow{2}{*}{ 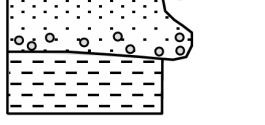 } & $40-50$ & 2 & Graded bedding coarse to medium sand. \\
\hline & $>30$ & 1 & Reddish brown clayey fine-sand. \\
\hline
\end{tabular}

Figure 4: Stratigraphic column of the Kedulan Site (modified after Dinas Kebudayaan dan Pariwisata Kabupaten Sleman, 2004 and Pramumijoyo et al., 2005). Lithology column is not proportionally scaled. 
the site in north-south direction in a distance of $328 \mathrm{~m}$ (Figure 6). Two runs were completed on the same line but different courses, i.e. forward and backward, where one was checked with another. Both runs were successfully identified and located the outer fence as well as other temple structures. Fences were recognized based on their strong amplitude and hyperbolic reflection pattern, whilst the three Perwara temples were registered as distinctive chaotic and discontinuous reflection with particular dimension.

The results indicate that the northern outer fence was located $66 \mathrm{~m}$ from the midpoint of the middle Perwara temple, which approximately lies at the same alignment with the midpoint of the main temple, thus can be regarded as the $\mathrm{E}-\mathrm{W}$ axis of the temple site. It is buried at a depth of $7 \mathrm{~m}$ (Figure 7). The northern inner fence was located $26 \mathrm{~m}$ from the E-W site axis and at a depth of $7 \mathrm{~m}$ (Figure 8). It gives a support to the hypothesis that the outer fence probably lies $40 \mathrm{~m}$ outside the inner fence, as suggested by the Sambisari Temple (Dinas Kebudayaan dan Pariwisata Kabupaten Sleman, 2004). This result also possibly indicates that the profane yard lies at the same elevation with the sacred yard.

The three Perwara temples base were located at a depth of $7 \mathrm{~m}$ while their top located at a depth of $4 \mathrm{~m}$ (Figure 9). It gives an approximate height of the Perwara temples of $3 \mathrm{~m}$. Their width range from about $4 \mathrm{~m}$ for the northern and southern Perwara temples and about $5 \mathrm{~m}$ for the middle Perwara temple. Those numbers agree with manual measurement on the temples base (Dinas Kebudayaan dan Pariwisata Kabupaten Sleman, 2004). The southern inner fence was located $27 \mathrm{~m}$ from the E-W site axis and at a depth of $7 \mathrm{~m}$ (Figure 10). The distance of the southern inner fence is slightly longer, i.e., $1 \mathrm{~m}$ longer, than the northern inner fence, as indicated by manual measurement, although the later gives a $2 \mathrm{~m}$ discrepancy (Dinas Kebudayaan dan Pariwisata Kabupaten Sleman, 2004).

The southern outer fence was located about $65 \mathrm{~m}$ from the E-W site axis, or $38 \mathrm{~m}$ from the inner fence, and at a depth of $7 \mathrm{~m}$ (Figure 11)

\section{Discussion}

The result indicates the presence of the outer fence is asymmetric relative to the main temple, similar to the inner fence as well. Its quadrangle dimension is $131 \times 131 \mathrm{~m}$, given $66 \mathrm{~m}$ to the north from the midpoint of the main temple and $65 \mathrm{~m}$ to the south. The inner fence has a quadrangle dimension of $53 \times 53 \mathrm{~m}$, given $26 \mathrm{~m}$ to the north from the midpoint of the main temple and $27 \mathrm{~m}$ to the south. This result are dissimilar to the manual measurement which indicates a quadrangle dimension of $39.6 \times 39.6$ $\mathrm{m}$, given $18.8 \mathrm{~m}$ to the north from the midpoint of the main temple and $20.8 \mathrm{~m}$ to the south (Dinas Kebudayaan dan Pariwisata Kabupaten Sleman, 2004). Those discrepancies are needed to be checked in the field by applying controlled measurement runs of the georadar. Nevertheless, the supposed distance of 38 to $40 \mathrm{~m}$ between the outer and inner fences are clearly indicated by the georadar (Figure 6). However, controlled measurement runs are needed to verify this distance. Problems in distance measurement rise due to technical design of the antennae cart where the measuring wheel was sometimes off ground during running over an uneven surface.

Assuming the fences were quadrangle relative to the main temple, hence it is estimated that the site area to the outer fence to be excavated is about $13,830 \mathrm{~m}^{2}$, yielded by 117.6 $\times 117.6 \mathrm{~m}$. Considered the depth of the temple structures is about $7 \mathrm{~m}$, then at least 96.808 $\mathrm{m}^{3}$ gravels and sands to be removed. So far, the excavation programme has removed covered deposits above the sacred yard (inside the inner fence) which was about $10,977 \mathrm{~m}^{3}$ gravels and sands, then there are $85,831 \mathrm{~m}^{3}$ covered deposits still left above the profane yard (between inner and outer fences) to be removed.

\section{Conclusions}

- Georadar is a useful method in detecting and locating buried archaeological objects. In the Kedulan Site, temples and fences are recognized based on their reflection pattern. Fences suggest a strong amplitude and hyperbolic reflection pattern, while 


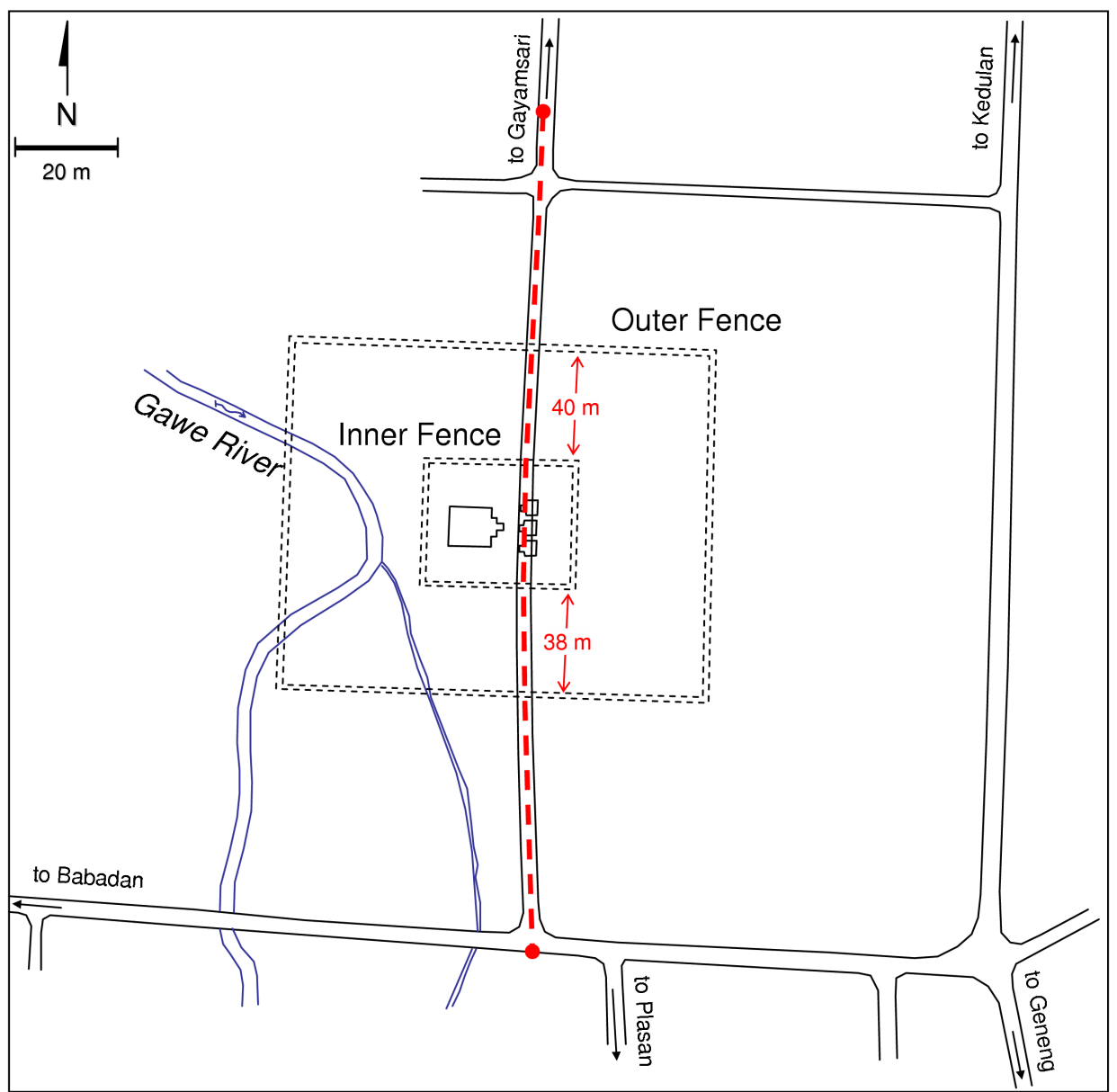

Figure 6: Schematic map of the Kedulan Site (Dinas Kebudayaan dan Pariwisata Kabupaten Sleman, 2004). Red dashed line indicates the georadar survey line. Distances between inner and outer fences as indicated by georadar survey are in red. Some objects are not proportionally scaled

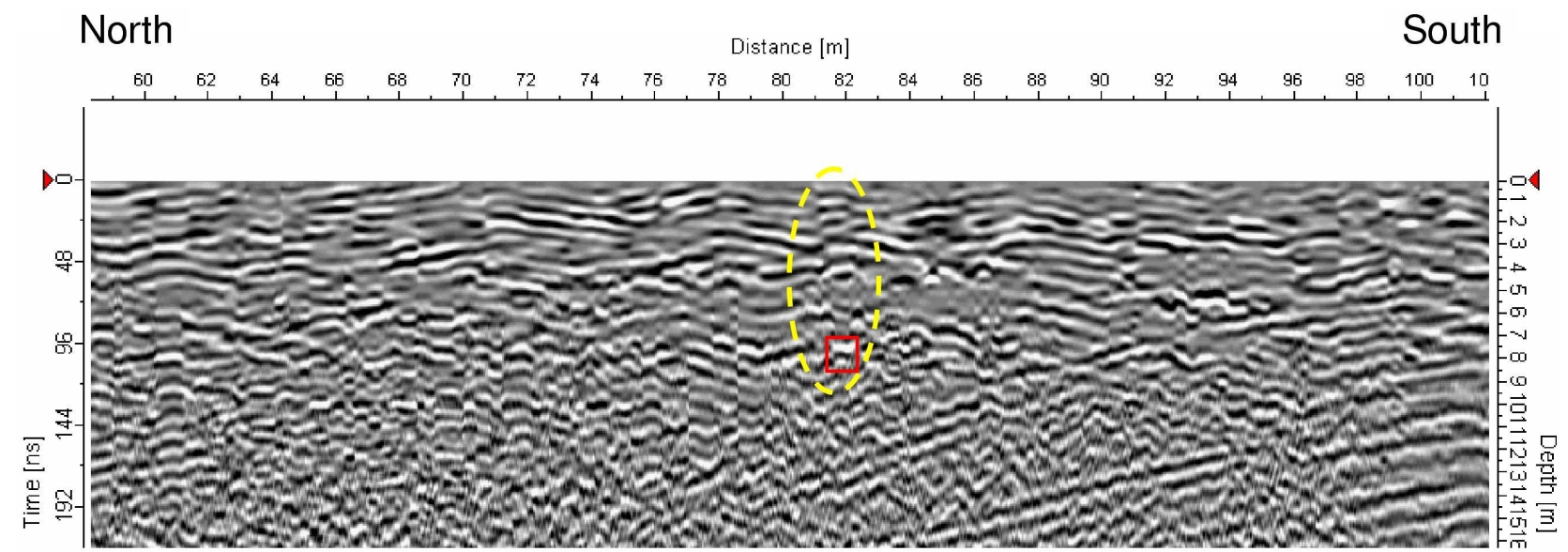

Figure 7: Reflection pattern of the northern outer fence (yellow curve line) and its location in depth (red square line) 
North

Distance $[\mathrm{m}]$

South

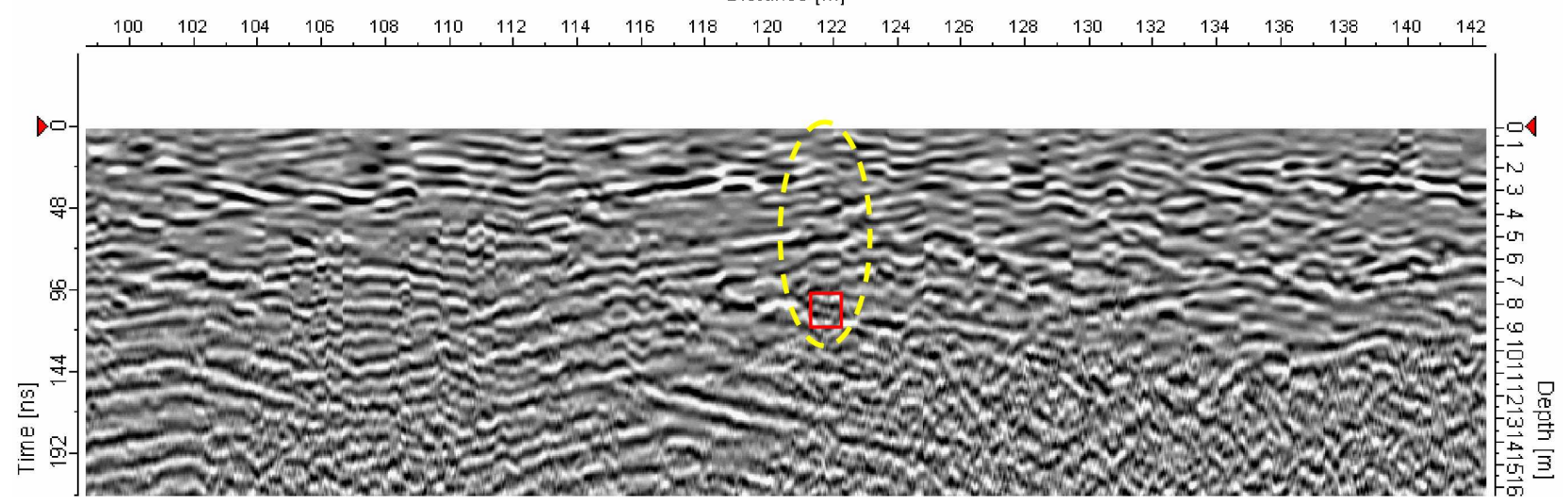

Figure 8: Reflection pattern of the northern inner fence (yellow curve line) and its location in depth (red square line)

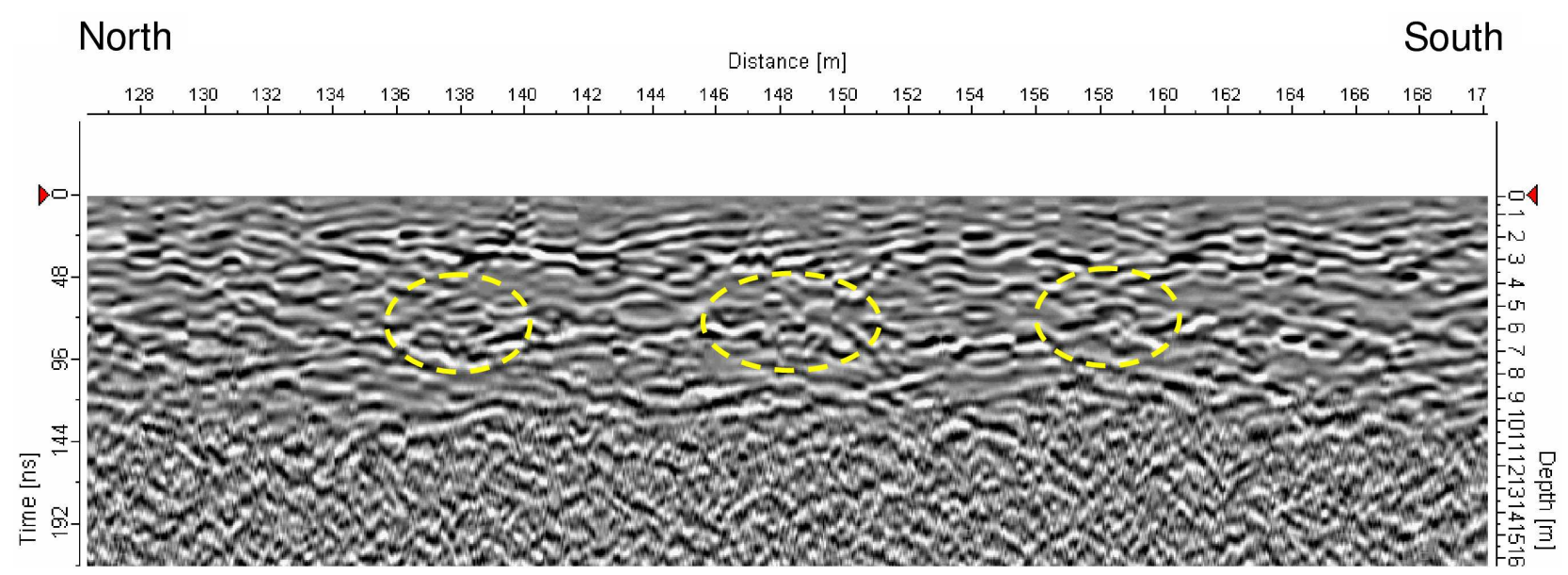

Figure 9: Reflection pattern of the three Perwara temples (yellow curve line)

\section{North}

Distance $[m]$

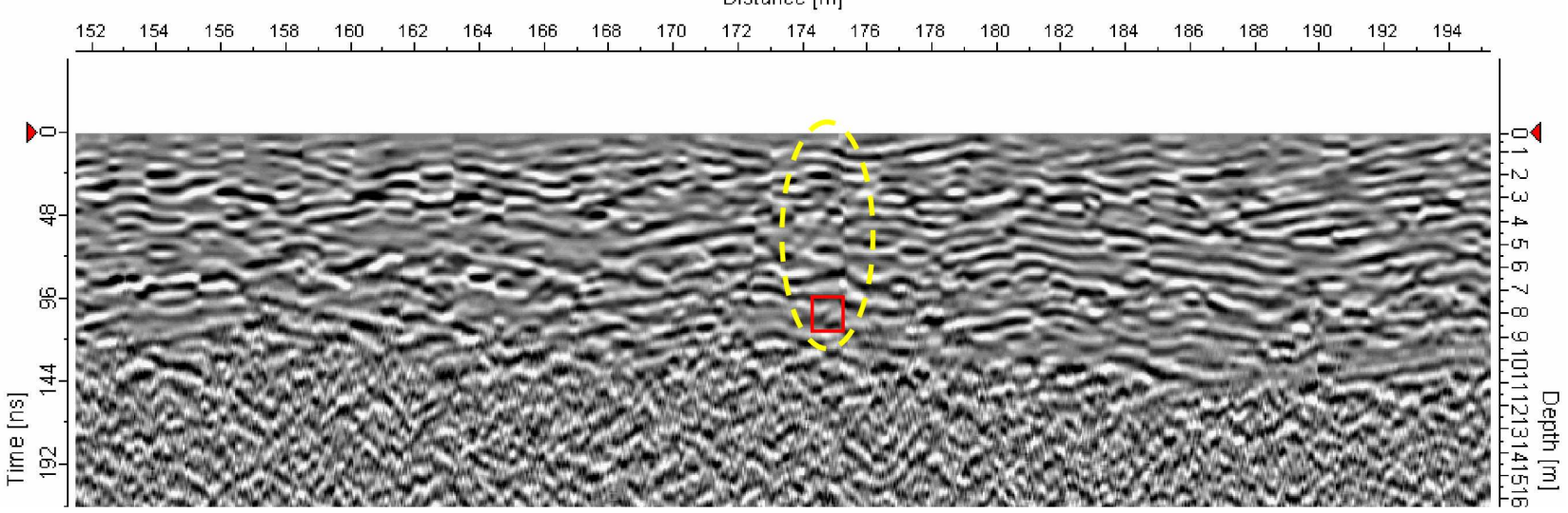

Figure 10: Reflection pattern of the southern inner fence (yellow curve line) and its location in depth (red square line) 


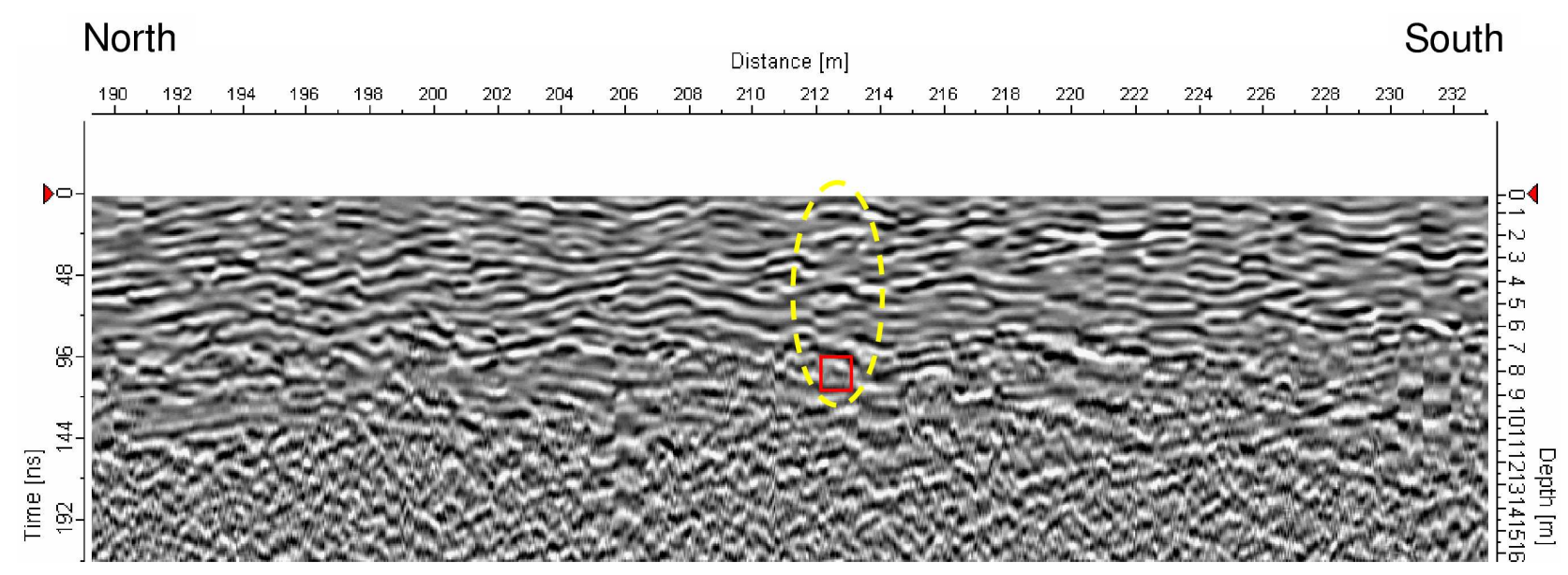

Figure 11: Reflection pattern of the southern outer fence (yellow curve line) and its location in depth (red square line)

temples suggest chaotic and discontinuous reflection.

- The location of the outer fence is about 40 $\mathrm{m}$ from the inner fence, as supposed by comparing to the Sambisari Temple. However, controlled measurement runs are needed to verify this preliminary result.

- The thickness of the covered fluviovolcanic deposit over the temple compound is about $7 \mathrm{~m}$. It gives a volume of $96,808 \mathrm{~m}^{3}$ gravels and sands to be removed during the excavation programme.

- Georadar investigation required a controlled measurement run for an accurate result, since the measuring wheel attached to the antennae cart is sometimes off ground while running over an uneven surface.

\section{References}

Dinas Kebudayaan dan Pariwisata Kabupaten Sleman (2004) Studi Teknis Arkeologis Situs Kedulan, $87 \mathrm{p}$.

Mala (2005) Groundvision Operating Manual Version 1.4, www.malags.com, 53 p.

Mulyaningsih, S., Sampurno, Y. Zaim, D.J. Puradimaja, S. Bronto, and D.A. Siregar (2006) Perkembangan Geologi pada KuarterAwal sampai Masa Sejarah di Dataran Yogyakarta. Jurnal Geologi Indonesia, Vol. 1 No. 2 Juni 2006, pp. 103-113.

Mulyaningsih, S. (1999) Rekonstruksi Bencana Alam Purba di Daerah Kalasan dan Sekitarnya, Daerah
Istimewa Jogjakarta. Jurusan Teknik Geologi, FIKTM, Institut Teknologi Bandung, 157 p. (unpublished thesis).

Mulyaningsih, S. (2006) Geologi Lingkungan di Daerah Lereng Selatan Gunung Api Merapi pada Waktu Sejarah (Historical Time). Departemen Teknik Geologi, Sekolah Tinggi Pascasarjana Institut Teknologi Bandung, 365 p. (unpublished dissertation).

Newhall, C.G., S. Bronto, B. Alloway, N.G. Banks, I. Bahar, M.A. del Marmol, R.D. Hadisantono, R.T. Holcomb, J. McGeehin, J.N. Miksic, M. Rubin, S.D. Sayudi, R. Sukhyar, S. Andreastuti, R.I. Tilling, R. Torley, D. Trimble, and A.D. Wirakusumah (2000) 10.000 Years of Explosive Eruptions of Merapi Volcano, Central Java: Archaelogical and Modern Implications. Journal of Volcanology and Geothermal Research, 100, pp. 9-50.

Pramumijoyo, S., M. Datun, Supangat, S. Surayati, and A. Setianto (2005) Renovation of Kedulan Temple, Yogyakarta and Geohazard Public Awareness Education. HAGI-IAGI Joint Convention Surabaya 2005, Surabaya.

Sismanto and E. Hartantyo (2006) Geophysical Study On Situs Of Kedulan Temple, 31st Annual Scientific Meeting (PIT) HAGI 2006, Semarang, A-017PT.

Widiyanto, A.E. and Sismanto (2006) Pendugaan Keberadaan Pagar Kedua Bagian Timur Situs Candi Kedulan Dengan Metode Resistivitas, 31st Annual Scientific Meeting (PIT) HAGI 2006, Semarang, A-027PT. 